\title{
Compositional variation during monogenetic volcano growth and its implications for magma supply to continental volcanic fields
}

\author{
K. NÉMETH ${ }^{1,3}$, J. D. L. WHITE ${ }^{1}$, A. REAY ${ }^{1} \&$ U. MARTIN ${ }^{2}$ \\ ${ }^{1}$ Geology Department, University of Otago, PO Box 56, Dunedin, New Zealand \\ ${ }^{2}$ TU-Bergakademia, Institut für Geologie, Freiberg, Germany \\ ${ }^{3}$ Present address: Magyar Állami Földtani Intézet (Geological Institute of Hungary), Stefánia út 14 Budapest, H-1143, \\ Hungary (email: nemeth_karoly@hotmail.com)
}

\begin{abstract}
Individual volcanoes of continental monogenetic volcanic fields are generally presumed to erupt single magma batches during brief eruptions. Nevertheless, in two unrelated volcanic fields (the Waipiata volcanic field, New Zealand, and the Miocene-Pliocene volcanic field in western Hungary), we have identified pronounced and systematic compositional differences among products of individual volcanoes. We infer that this indicates a two-stage process of magma supply for these volcanoes. Each volcano records: (1) intrusion of a basanitic parent magma to lower- to mid-crustal levels and its subsequent fractionation to form a tephritic residual melt; (2) subsequent transection of this reservoir by a second batch of basanitic melt, with tephrite rising to the surface at the head of the propagating basanite dyke. Eruption at the surface then yields initial tephrite, typically erupted as pyroclasts, followed by eruption and shallow intrusion of basanite from deeper in the dyke. By analogy with similar tephrite-basanite eruptions along rift zones of intraplate ocean-island volcanoes, we infer that fractionation to tephrite would have required decades to centuries. We conclude that the two studied continental monogenetic volcanic fields demonstrate a consistent history of early magmatic injections that fail to reach the surface, followed by capture and partial eruption of their evolved residues in the course of separate and significantly later injections of basanite that extend to the surface and erupt. This systematic behaviour probably reflects the difficulty of bringing small volumes of dense, primitive magma to the surface from mantle source regions. Ascent through continental crust is aided by the presence in the dyke head of buoyant tephrite captured during transection of the earlier-emplaced melt bodies.
\end{abstract}

Keywords: Otago, Pannonian Basin, magmas, composition, volcanism.

Monogenetic volcanoes are small and occur as scoria cones, tuff cones and rings, and maars; they form from single, typically brief eruptions (Walker 1993). Monogenetic volcanoes form in two distinct settings: (1) as isolated fields of volcanoes on continental lithosphere, ranging from thinned lithosphere $(<30 \mathrm{~km})$ resulting from stretching and extension (e.g. Ethiopia (Barberi \& Varet 1970; Ebinger et al. 1993) and the Basin and Range province (Brandon \& Goles 1995)) to normal or thick lithosphere (e.g. the San Francisco field (Conway et al. 1998) and Hopi Buttes (White 1991)); (2) as 'parasitic' vents along the rift zones or flanks of large polygenetic central volcanoes (e.g. Tolbachik (Doubik \& Hill 1999), La Palma (Klügel et al. 1999) and Hawaii (Moore 1992)).

Some single eruptions forming monogenetic volcanoes atop large central volcanoes are known to have produced petrologically varied magmas (Klügel 1997, 1998; Klügel et al. 1999, 2000) that reflect the presence of magma reservoirs within the large volcano. Such variation has not been noted in single smallvolume monogenetic volcanoes typical of continental fields, which are thought to lack stable magma storage zones. These volcanoes are formed by more or less direct eruption of magma from the mantle, with each volcano resulting from successful propagation of a small batch of magma to the surface along a new pathway (Spera 1984; Hasenaka \& Carmichael 1985, 1987; Connor et al. 2000). In this paper, we present evidence for similar, single-eruption, compositional variation in products of two widely separated and unrelated continental monogenetic volcanic fields, and suggest that the 'plumbing systems' and magma supply dynamics for such fields may be more nuanced than hitherto appreciated.

\section{Waipiata and western Hungarian volcanic fields}

The Waipiata volcanic field occupies an area of c. $5000 \mathrm{~km}^{2}$ onland in southeastern New Zealand (Fig. 1) and continues offshore over a similar, but very poorly constrained, area. It formed between c. 16 and $12 \mathrm{Ma}$ (Coombs et al. 1986), on continental crust of $>30 \mathrm{~km}$ thickness (Koons et al. 1999) during a period of mild crustal extension (King 2000). In this study, remnants of 55 volcanoes of the Waipiata volcanic field were examined (Németh 2001), some $75 \%$ of which comprise glassy pyroclastic rocks intruded by dykes and sills, and/or overlain by lavas.

An intracontinental Miocene-Pliocene volcanic field in western Hungary developed between 7.56 and $2.3 \mathrm{Ma}$ (Balogh et al. 1986) across an area half the size of the Waipiata volcanic field (Fig. 1). There are two distinct parts to the western Hungarian volcanic field (Fig. 1), and these developed together in a tectonic regime that varied during that time from transtensional to transpressional (Fodor 1995). Volcanoes of the western Hungarian volcanic field also consistently comprise basal glassy pyroclastic units overlain by lavas that cap buttes (Németh \& Martin 1999).

The pyroclastic rocks of each of the studied parts of the western Hungarian volcanic field contain various proportions of country rock clasts (Fig. 2), and apparently represent vent-filling 


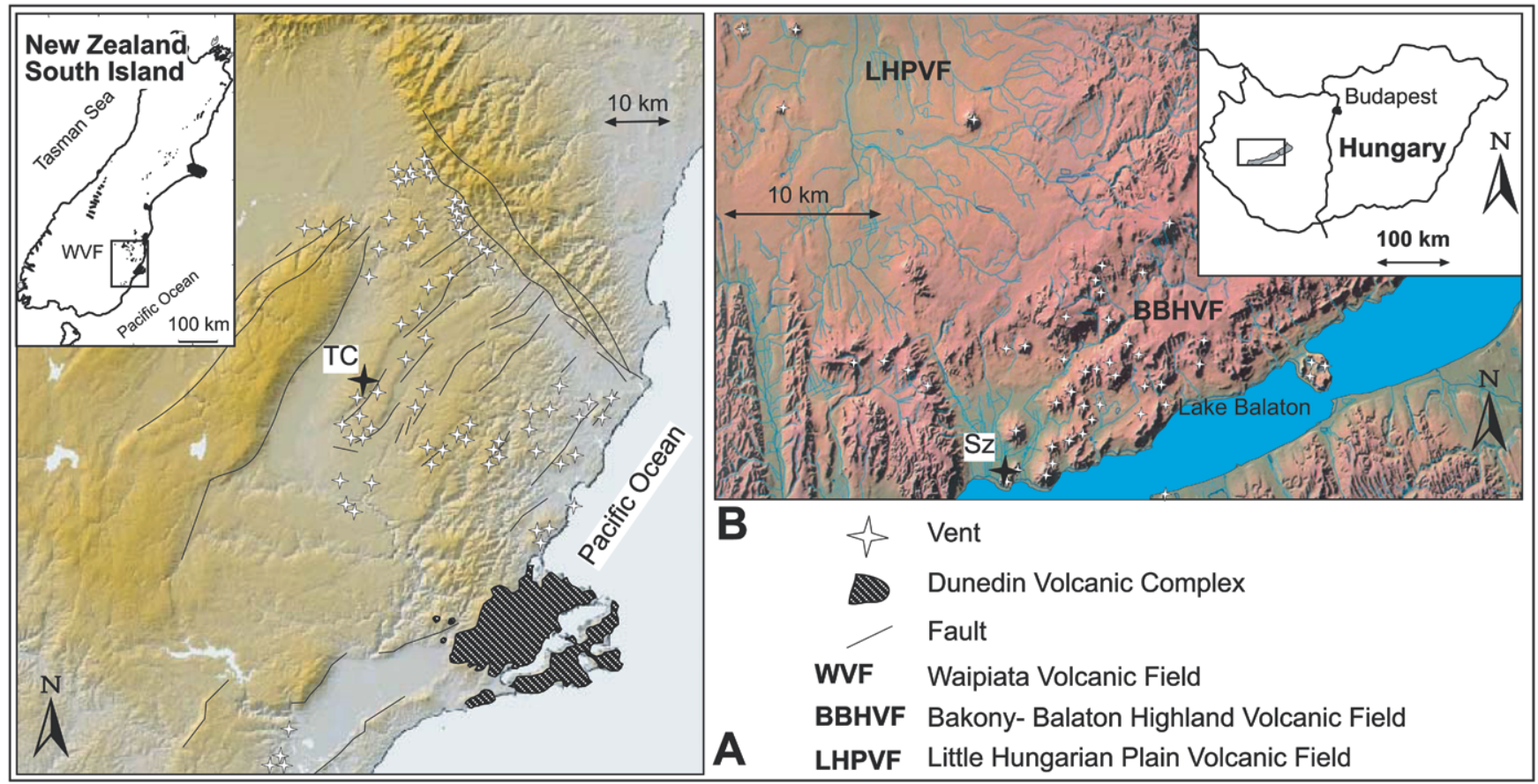

Fig. 1. Overview maps of the two studied volcanic fields. (a) Waipiata volcanic field in the South Island of New Zealand; (b) small-volume intracontinental volcanic fields in western Hungary. TC, 'The Crater'; Sz, Szigliget.

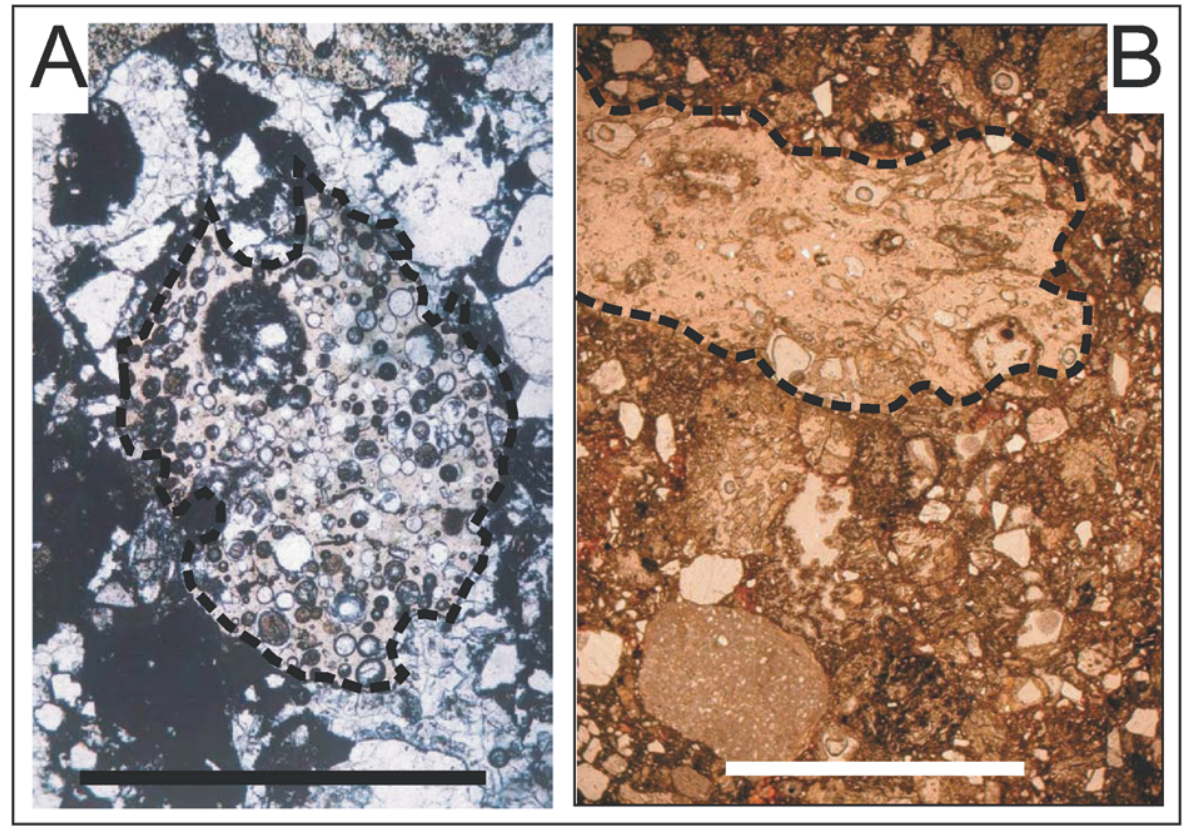

Fig. 2. Photomicrographs of representative volcanic glass shards from the studied volcanic fields. (a) 'The Crater'; (b) Szigliget. The moderately vesicular texture of the glass shards, and the paucity of microlites, should be noted. Scale bars represent $1 \mathrm{~mm}$. assemblages and locally preserved well-bedded tuff ring deposits. Dykes and lavas have subplanar to highly irregular, locally peperitic (Martin \& Németh 2000), contacts with pyroclastic rocks, suggesting intrusion soon after emplacement of the tuffs and tuff breccias while they were still unconsolidated. The pyroclastic rocks typically have aphyric or sparsely feldsparphyric juvenile clasts (Fig. 2), whereas the slightly younger dykes and lavas are characterized by abundant pyroxene \pm kaersutite phenocrysts. There are abundant deep-seated cumulate fragments, $1-15 \mathrm{~cm}$ in size, in the topmost beds of pyroclastic deposits at some of the volcanoes.

\section{Analytical methods and results}

Samples of pyroclastic rocks were examined in thin section, and those containing remnants of fresh, isotropic glass were analysed 
by electron microprobe to obtain glass compositions. The juvenile clasts themselves are glassy or palagonitic, with variably abundant feldspar and pyroxene microlites as well as occasionally some larger plagioclase phenocrysts of andesine composition (An 50\%). Vesicularity estimated from thin section ranges from a few percent to perhaps up to $50 \%$, with typical clasts of moderate vesicularity $(<25 \%)$ (Fig. 2). Vesicles are small, generally circular to elliptical in section (Fig. 2), and separated by thick glass walls; such pyroclasts are generally interpreted to result from phreatomagmatic eruption processes (Heiken 1974; Fisher \& Schmincke 1984; White \& Houghton 2000).

Results of microprobe analyses of pyroclast glass were compared with existing whole-rock XRF analyses of dykes and lavas from the same volcanoes (Embey-Isztin 1993; Donnelly 1996; Figs 3 and 4, Table 1). Deposits of 'The Crater' typify features of single volcanoes in the Waipiata volcanic field (Németh 2000), and have pyroclastic rocks with less $\mathrm{MgO}$, less $\mathrm{FeO}_{\mathrm{t}}$, and more $\mathrm{K}_{2} \mathrm{O}$ than dykes and lavas from the same vent (Fig. 4a and b; Table 1). CIPW norm calculations indicate that the pyroclast glasses are tephrite (regardless of $\mathrm{Fe}_{2} \mathrm{O}_{3}$ to $\mathrm{FeO}$ ratios chosen), and lavas are basanite (Table 1). A similar degree of composi-

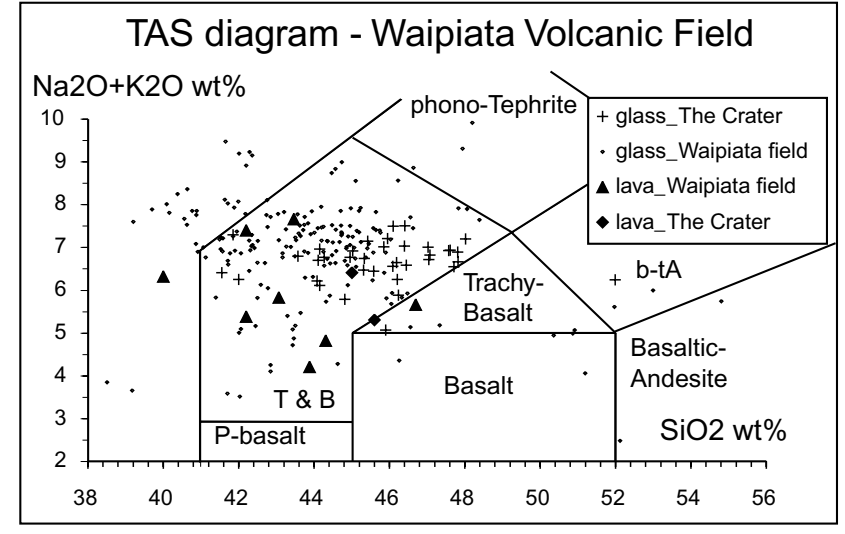

Fig. 3. Total alkali v. silica (TAS) diagram for volcanic glass shards and lava flows from throughout the Waipiata field. Because TAS differences within single volcanoes are modest, and vary across different ranges, the fields for glass shard and lava compositions are not distinct in this diagram.

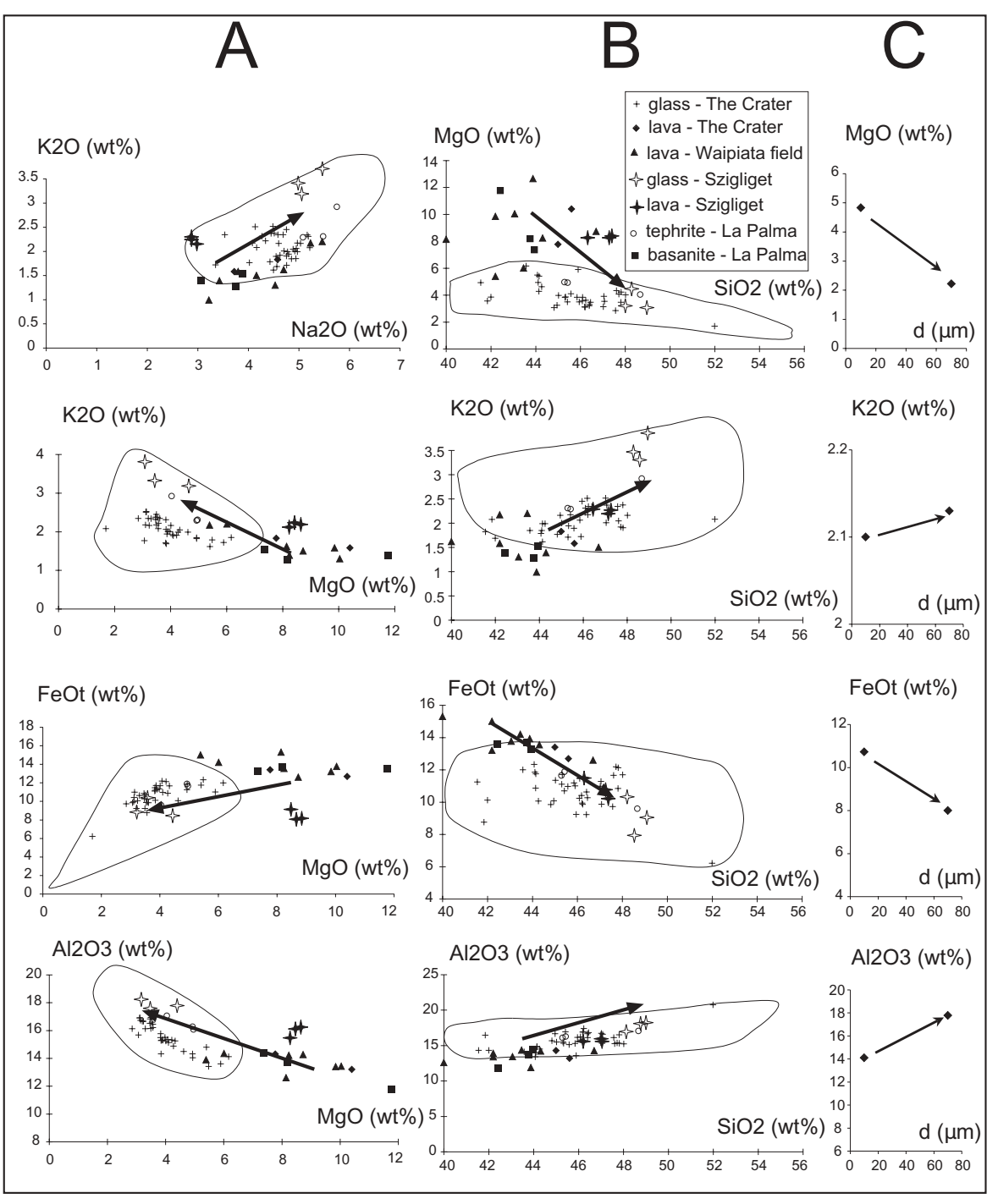

Fig. 4. Major element discrimination diagrams for volcanic glass shards and lava flows from individual volcanoes in the Waipiata volcanic field (WVF) and western Hungary. From the Waipiata volcanic field, data from a single volcanic remnant are presented (glass and lava from 'The Crater'). For comparison with other lava flow compositions, each diagram shows the data field for all Waipiata lava flows (lava Waipiata field). From western Hungary, data from a similar vent remnant are shown (glass - Szigliget; lava - Szigliget). The outlined field represents all glass data from both the Waipiata field and western Hungarian fields. In (a), $\mathrm{Na}_{2} \mathrm{O}$ v. $\mathrm{K}_{2} \mathrm{O}$ and $\mathrm{MgO}$ v. $\mathrm{K}_{2} \mathrm{O}, \mathrm{FeO}_{\text {total }}$ and $\mathrm{Al}_{2} \mathrm{O}_{3}$ are plotted. (Note the separation of data representing volcanic glass shards v. lava flows, suggesting fractional crystallization with separation of olivine, minor clinopyroxene and magnetite.) In (b), representative Harker diagrams $\left(\mathrm{SiO}_{2}\right.$ v. $\mathrm{MgO}, \mathrm{K}_{2} \mathrm{O}, \mathrm{FeO}_{\mathrm{t}}$ and $\mathrm{Al}_{2} \mathrm{O}_{3}$ ) are plotted, showing crystal fractionation trends between volcanic glass shards and lava flows. In each frame of (a) and (b), data from the La Palma eruption are also plotted to illustrate the similar fractionation trend for La Palma, the Waipiata volcanic field and western Hungary. (c) shows the effect on 'apparent' composition of using larger electron beam diameter ( $\mathrm{d}$; abscissa in $\mu \mathrm{m}$ ) during electron microprobe measurements of glass shards. It should be noted that increasing beam diameter leads to lower measured values of $\mathrm{MgO}$ and $\mathrm{FeO}_{\mathrm{t}}$, thus yielding lower values of normative olivine in CIPW calculation. We used the smaller of the beam diameters, thus conservatively biasing glass measurements to less tephritic compositions. 
Table 1. Composition of volcanic glass shards from 'The Crater', Waipiata volcanic field, compared with XRF data from associated lava flows (first two columns)

\begin{tabular}{|c|c|c|c|c|c|c|c|c|}
\hline Sample: & CRb-272 & CRb2-307 & CR2-320 & CR15-330 & CR23-334 & CR22-342 & CR8-dyke & CR3-dyke \\
\hline $\mathrm{SiO}_{2}$ & 45.42 & 47.02 & 46.41 & 47.05 & 47.82 & 48.02 & 45 & 45.6 \\
\hline $\mathrm{Al}_{2} \mathrm{O}_{3}$ & 16.94 & 16.72 & 16.13 & 15.3 & 15.31 & 15.24 & 2.46 & 2.15 \\
\hline $\mathrm{TiO}_{2}$ & 2.85 & 2.7 & 2.47 & 3.09 & 2.93 & 2.86 & 14.3 & 13.2 \\
\hline $\mathrm{FeO}$ & 10.69 & 10.98 & 10.63 & 11.28 & 12.13 & 11.7 & 13.4 & 12.69 \\
\hline $\mathrm{MnO}$ & 0.11 & 0.13 & 0.18 & 0.08 & 0.16 & 0.29 & 0.22 & 0.19 \\
\hline $\mathrm{MgO}$ & 3.5 & 3.14 & 3.3 & 3.91 & 4.22 & 4.01 & 7.77 & 10.4 \\
\hline $\mathrm{CaO}$ & 7.78 & 8.33 & 8.38 & 9.64 & 9.24 & 9.37 & 8.12 & 8.16 \\
\hline $\mathrm{Na}_{2} \mathrm{O}$ & 4.97 & 4.49 & 5.17 & 4.71 & 4.75 & 5.03 & 4.58 & 3.72 \\
\hline $\mathrm{K}_{2} \mathrm{O}$ & 2.17 & 2.51 & 2.34 & 2.01 & 1.91 & 2.16 & 1.83 & 1.58 \\
\hline $\mathrm{Na}_{2} \mathrm{O}+\mathrm{K}_{2} \mathrm{O}$ & 7.14 & 7 & 7.51 & 6.71 & 6.66 & 7.2 & 6.41 & 5.3 \\
\hline Total & 94.43 & 96.02 & 95.01 & 97.06 & 98.48 & 98.68 & 99.55 & 99.38 \\
\hline $\mathrm{SiO}_{2}$ & 48.1 & 48.97 & 48.85 & 48.48 & 48.56 & 48.66 & 45 & 45.6 \\
\hline $\mathrm{TiO}_{2}$ & 3.02 & 2.81 & 2.6 & 3.18 & 2.98 & 2.9 & 2.46 & 2.15 \\
\hline $\mathrm{Al}_{2} \mathrm{O}_{3}$ & 17.94 & 17.41 & 16.98 & 15.76 & 15.55 & 15.44 & 14.3 & 13.2 \\
\hline $\mathrm{FeO}$ & 11.32 & 11.44 & 11.18 & 11.62 & 12.32 & 11.86 & 13.4 & 12.69 \\
\hline $\mathrm{MnO}$ & 0.12 & 0.14 & 0.19 & 0.08 & 0.16 & 0.29 & 0.22 & 0.19 \\
\hline $\mathrm{MgO}$ & 3.71 & 3.27 & 3.47 & 4.03 & 4.29 & 4.06 & 7.77 & 10.4 \\
\hline $\mathrm{CaO}$ & 8.24 & 8.68 & 8.82 & 9.93 & 9.38 & 9.5 & 8.12 & 8.16 \\
\hline $\mathrm{Na}_{2} \mathrm{O}$ & 5.26 & 4.68 & 5.44 & 4.85 & 4.82 & 5.1 & 4.58 & 3.72 \\
\hline $\mathrm{K}_{2} \mathrm{O}$ & 2.3 & 2.61 & 2.46 & 2.07 & 1.94 & 2.19 & 1.83 & 1.58 \\
\hline $\mathrm{Na}_{2} \mathrm{O}+\mathrm{K}_{2} \mathrm{O}$ & 7.56 & 7.29 & 7.9 & 6.92 & 6.76 & 7.29 & 6.41 & 5.3 \\
\hline Total & 100 & 100 & 100 & 100 & 100 & 100 & 99.55 & 99.38 \\
\hline Mg-number & 0.43 & 0.4 & 0.42 & 0.46 & 0.45 & 0.44 & 0.57 & 0.65 \\
\hline $\mathrm{ol}$ & 4.6 & 3.53 & 2.62 & 1.77 & 3.78 & 2.49 & 16.97 & 21.64 \\
\hline or & 13.58 & 15.45 & 14.55 & 12.24 & 11.46 & 12.94 & 10.81 & 9.34 \\
\hline$a b$ & 19.7 & 20.31 & 18.14 & 18.49 & 20.75 & 18.32 & 16.67 & 18.7 \\
\hline ne & 13.45 & 10.43 & 15.11 & 12.23 & 10.87 & 13.44 & 11.96 & 6.92 \\
\hline an & 18.54 & 18.8 & 14.62 & 15.11 & 15.04 & 12.79 & 13.06 & 14.65 \\
\hline D.I. & 46.74 & 46.19 & 47.81 & 42.96 & 43.08 & 44.7 & 39.45 & 34.96 \\
\hline
\end{tabular}

Analyses were performed by electron microprobe (JEOL 8600 Superprobe at the Geology Department, Otago University), using $15 \mathrm{kV}$ acceleration voltage, $10-20 \mu \mathrm{m}$ electron beam diameter on polished thin sections and OXIDE9 standard. First set of data represents raw chemical composition; second set represents data normalized to $100 \%$. CIPW norms were calculated for $0.3 \mathrm{Fe}_{2} \mathrm{O}_{3}$ to $\mathrm{FeO}$ ratios. Mg-number, magnesium number; ol, normative olivine; or, normative orthoclase; ab, normative albite; ne, normative nepheline; an, normative anorthite; D.I., differentiation index. The total values varied between 94 and $99 \%$ on measured volcanic glass shards from lapilli tuffs and tuffs. This variation seems only to manifest in the $\mathrm{SiO}_{2}$ content of the measured glass shard indicating $\mathrm{SiO}_{2}$ loss of the glass shard. However the deeper reason of such effect needs further investigation. For the comparison of various data sets a uniform normalization has been applied on each glass shard data. Glass shard data over $97 \%$ of total values is generally considered a very good measurement in microprobe studies and perhaps a $100 \%$ normalization does not give significantly new results in calculation of CIPW norms.

tional variation between pyroclast glasses of phreatomagmatic pyroclastic rocks and intruding dykes has been recognized from the vent remnant of Szigliget, western Hungary (Németh et al. 2000) (Fig. 4; Table 1).

The studied pyroclasts contain modest proportions of microlites and few or no phenocrysts, which allows comparison with whole-rock XRF results. Use of a wide electron beam $(>50 \mu \mathrm{m})$ captures both glass and local microlite compositions, and yields similar $\mathrm{SiO}_{2}$ values coupled with increased total alkalis (Fig. 4c) and higher totals overall. We infer that these differences result from capture of a mixture of feldspar and/or clinopyroxene microlites and glass within the larger beam, and these results reveal rocks that are even more clearly tephritic to phonotephritic, supporting our interpretation of a substantial difference in composition between the pyroclastic rocks and subsequently emplaced dykes and lavas. Modelling of major element trends indicates that the tephrite could have been formed from a basanite parent by simple crystal fractionation dominated by removal of $10-20 \%$ olivine plus minor $(<5 \%)$ titanomagnetite and/or clinopyroxene. All of these phases are present in the basanite lavas (Coombs \& Reay 1986; Coombs et al. 1986), and are plausible fractionating phases to produce the tephrites.

\section{Discussion}

The eruption of both tephrite and basanite during single eruptions of a continental monogenetic volcanic field is unexpected, because each volcano and eruption occupies a new site, each volcano is too short lived to develop its own magma chamber in which differentiation might take place, and the time necessary for differentiation of a basanite parent to tephrite far exceeds the duration of an eruption or of magma transport from source to surface (Table 2).

As indicated by Table 2, differentiation of basanite parent magma to tephrite is, however, commonplace in polyphase alkaline volcanoes. In the Eifel volcanic field, the Rothenberg volcano, which had an original edifice volume of some $0.05 \mathrm{~km}^{3}$ (Houghton \& Schmincke 1989) records a number of eruptions that tapped progressively a zoned magma chamber developed at upper-mantle and/or mid-crustal levels (30-20 km; Schmincke 1977a, 1977b; Duda \& Schmincke 1978; Schmincke et al. 1983). Such repeatedly tapped, zoned, magma columns are believed to form over hundreds (to thousands?) of years (Hawkesworth et al. 2000) from a mafic parent magma. In contrast, individual eruptions playing a part in the construction of Rothenberg volcano probably had durations of days to months on the basis of its sedimentary record (Houghton \& Schmincke 1986; Houghton \& Schmincke 1989).

In 1949, both basanite and tephrite were ejected during a single, 5 week long eruption that formed monogenetic cones and lava flows on the volcanic island of La Palma, Canary Islands (Klügel et al. 1999; White \& Schmincke 1999). In this case, the tephrite is inferred to have formed from a basanite parent magma that was injected into the island volcano's deep rift zone in the 
Table 2. Summary comparison of the time scales of magma rise speed (time), eruption duration, and magma differentiation time, with notes on the calculation methods and locations

\begin{tabular}{|c|c|c|}
\hline Time scales & Notes & Reference \\
\hline Magma rise speed and/or time & Basis of calculation & \\
\hline Few hours to 4 days from lower crust to the surface & $\begin{array}{l}\text { La Palma, Canary Island; } \mathrm{Fe}-\mathrm{Mg} \text { interdiffusion at xenolith } \\
\text { fractures }\end{array}$ & Klügel 1998 \\
\hline $0.1-10 \mathrm{~m} \mathrm{~s}^{-1}$ from source & $\begin{array}{l}\text { Xenolith settling velocity (Stoke's law) applied to varying } \\
\text { fluid behaviour }\end{array}$ & Sparks et al. 1977 \\
\hline $\begin{array}{l}36 \mathrm{~h} \text { from mantle to Moho }\left(0.1 \mathrm{~m} \mathrm{~s}^{-1}\right) \text { and } 1.5 \mathrm{~h} \text { from } \\
\text { Moho to surface }\left(5 \mathrm{~m} \mathrm{~s}^{-1}\right)\end{array}$ & $\begin{array}{l}\text { Nógrad-Gömör volcanic field, Hungary alkali basalt hosted } \\
\text { xenoliths; fluid inclusion study }\end{array}$ & Szabó \& Bodnar 1996 \\
\hline $\begin{array}{l}0.1 \mathrm{~m} \mathrm{~s}^{-1} \text { from mantle to Moho then } 10 \mathrm{~m} \mathrm{~s}^{-1} \text { from Moho } \\
\text { to surface }\end{array}$ & $\mathrm{CO}_{2}$ inclusion study of peridotite lherzolite nodules & Spera 1984 \\
\hline Eruption duration & Location of eruption and its type & \\
\hline $\begin{array}{l}\text { c. } 1300 \text { days ( } 14 \text { November } 1963-1967) \text { with distinct } \\
\text { active periods lasting for days from various vent sites }\end{array}$ & Surtsey, Iceland; surtseyan style subaqueous to emergent & Thorarinsson 1967 \\
\hline $10-20 \mathrm{~h}(1-2$ January 1996$)$ & Karymskoye lake, Kamchatka; surtseyan style sub-lacustrine & Belousov \& Belousova 2001 \\
\hline $\begin{array}{l}10 \text { days ( } 30 \text { March } 1977-09 \text { April } 1977), 147 \mathrm{~h} \text { duration } \\
\text { for small-volume lava extrusion }\end{array}$ & $\begin{array}{l}\text { Ukinrek, Alaska; two maar-forming phreatomagmatic, } \\
\text { terrestrial eruptions }\end{array}$ & $\begin{array}{l}\text { Self et al. 1980; Kienle et al. } \\
1980\end{array}$ \\
\hline 3 days (1965) & Taal, Philippines; phreatomagmatic eruption & Moore et al. 1966 \\
\hline $\begin{array}{l}100 \text { days (1955) with a more active period in the beginning } \\
\text { lasting for days, then activity changed to fumarole steam }\end{array}$ & $\begin{array}{l}\text { Nilahue, Chile; maar-forming eruption with repeated } \\
\text { explosive activity }\end{array}$ & Müller \& Veyl 1956 \\
\hline 38 days (1949) & $\begin{array}{l}\text { La Palma, Canary Islands; phreatomagmatic explosive } \\
\text { eruptions and lava flows }\end{array}$ & Klügel et al. 1999, 2000 \\
\hline Magma differentiation time & Location and basis of calculation & \\
\hline $\begin{array}{l}\text { Basalt through andesite to dacite, } 1-4 \mathrm{ka} \\
\text { Basalt to rhyolites, } 5-6 \mathrm{ka}\end{array}$ & Tonga/Kermadec; $\mathrm{U}-\mathrm{Th}-\mathrm{Ra}$ isotope series & Turner et al. 2000 \\
\hline Basanite to phonolite via $50 \%$ crystal fractionation, $10 \mathrm{ka}$ & Tenerife, Canary Islands; $\mathrm{U}-\mathrm{Th}-\mathrm{Ra}$ isotope series & Hawkesworth et al. 2000 \\
\hline $\begin{array}{l}\text { Phonolite to more evolved phonolite via } 50 \% \text { crystal } \\
\text { fractionation, a few hundred years }\end{array}$ & Tenerife, Canary Islands; U-Th-Ra isotope series & Hawkesworth et al. 2000 \\
\hline Hawaiite to mugearite, $<200$ years & Mt Etna, Italy; U-Th-Ra isotope series & Condomines et al. 1995 \\
\hline Basanite to phonolite, $100 \mathrm{ka}$ & Laacher See, Germany; U-Th-Ra isotope series & Bourdon et al. 1994 \\
\hline Alkali basalt to trachyte, $90 \mathrm{ka}$ & São Miguel, Azores; U-Th-Ra isotope series & Widom et al. 1992 \\
\hline $\begin{array}{l}\text { Basanite to tephrite, phonotephrite, }>13 \text { years (small, } \\
\text { shallow batches) }\end{array}$ & La Palma, Canary Islands; historic account (13 years) & Klügel et al. 2000 \\
\hline Basanite to tephrite in mantle, a century or more & $\begin{array}{l}\text { Tephrites not petrologically derived from historically } \\
\text { erupted magmas }\end{array}$ & \\
\hline Basanite to phonolite, $<150 \mathrm{ka}$ & Mt Erebus, Antarctica; U-Th-Ra isotope series & Reagan et al. 1992 \\
\hline
\end{tabular}

upper mantle (200-350 MPa, c. $15 \mathrm{~km}$, Moho at ocean-island setting) no later than 1936, the time of the most recent preceding eruption (Klügel et al. 2000); this eruption also emplaced some magma higher into the volcanic edifice. After at least 13 years of differentiation (probably more) at depth to produce tephrite, a new injection of basanite transected the deep reservoir, following to the surface tephrite magma that collected additional, phonotephritic magma, from small high-level reservoirs en route (Klügel et al. 2000).

A key feature of tephrite-basanite successions, then, is that they reflect evolution of a basanite parent magma over time. When basanite and tephrite are erupted together, as at La Palma in 1949, eruption of magmas from different batches, with different crystal fractionation histories, is inferred (Klügel et al. 2000). In the Waipiata and western Hungarian volcanic fields, basanite and tephrite occur together in volcanoes that were neither large and long lived enough to have developed their own differentiated magma columns (compare Rothenberg) nor associated with the magma storage system of a larger, underlying volcano (compare La Palma). How, then, can we interpret their co-occurrence?

The simplest explanation is that the general assumption that continental monogenetic volcanic fields lack significant shallow magma storage zones (Connor \& Conway 2000) must be in error. We infer for the Waipiata field that each 'successful' eruption that produces a monogenetic volcano represents at least two injections of magma from the source region (mantle), with the earlier of these injections stalling and differentiating at regions such as rheological and/or density boundaries of the lithosphere (e.g. upper-mantle-lower-crustal and/or lower-upper-crustal levels). Each volcano records one eruption, but also carries the residual products of one or more 'failed eruptions' that leave magma pockets ponded in temporary storage places.

The tephrite-basanite association occurs at many volcanoes of the Waipiata and western Hungarian volcanic fields, and we consider two scenarios to explain this (Fig. 5).

In the first scenario, the sites of the Waipiata and western Hungarian volcanic fields may have initially offered unfavourable stress conditions for transport of small magma batches from mantle source regions to the surface, and injected magma was consistently captured and stored at rheological and/or density boundaries of the lithosphere (Walker 1989; Head \& Wilson 1992; Rubin 1995; Watanabe et al. 1999). Later, stress conditions became more favourable for magma transport, and injected batches consistently reached the surface, transecting bodies of evolved magma along the way.

In this scenario, thermal decay times require that there was an abrupt switch from one stress regime to another, and that all volcanoes within each field would be of similar ages. Although dating within both fields has been limited, there is a range of some millions of years among dated lavas of each field. This is too long to preserve small bodies of melt in the crust, and suggests that the scenario is appropriate to neither the Waipiata nor the western Hungarian field.

In the second scenario, throughout the area of the Waipiata and western Hungarian volcanic fields, magma was injected to form small (kilometre-scale) mid-crustal magma bodies, then 


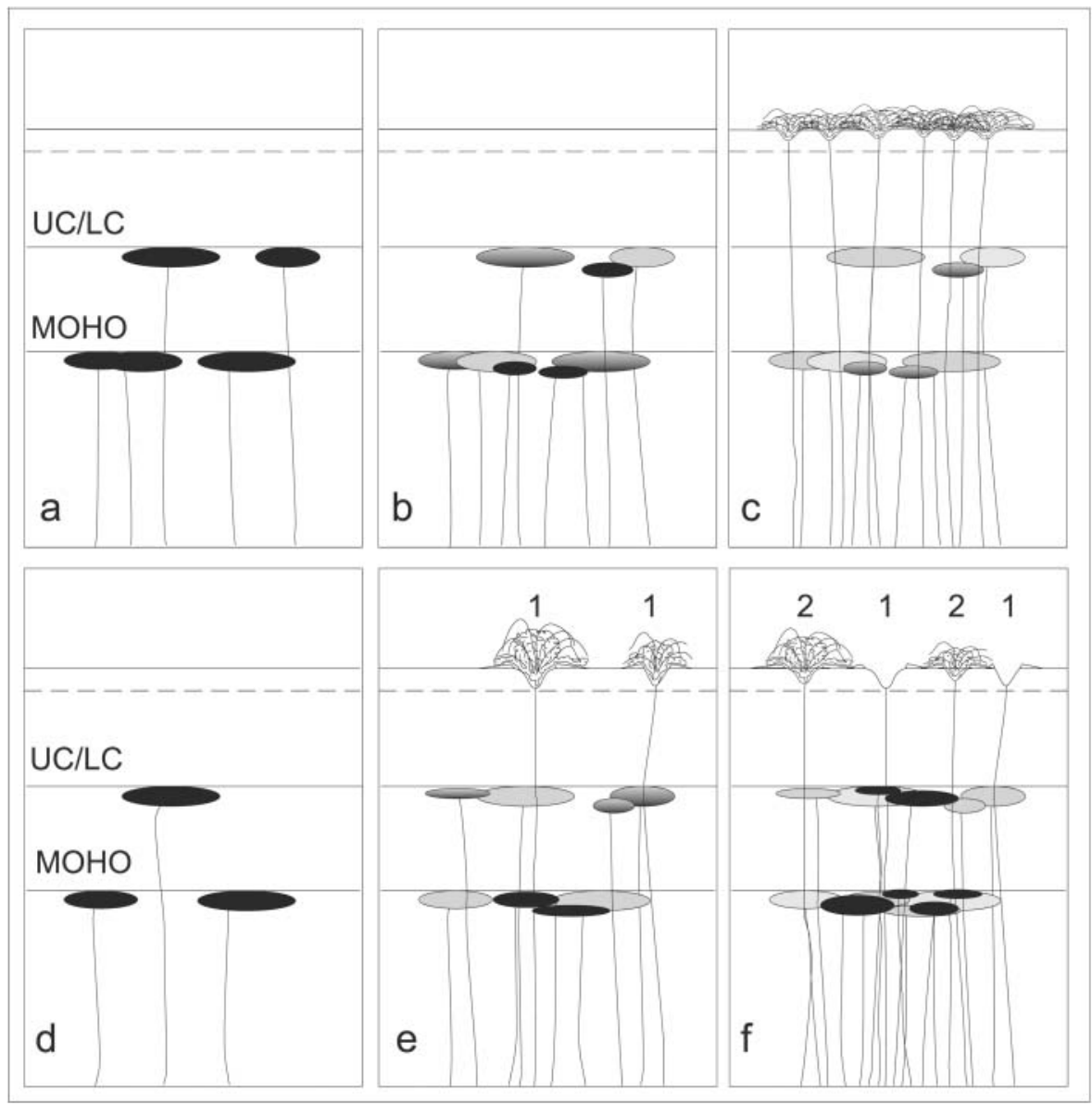

Fig. 5. Simple model for a monogenetic volcanic field magmatic plumbing system. (a) -(c) illustrate a scenario with initial magmatic underplating, during which magmas are not erupted to the surface because of unfavourable stress regime, and individual basanite melt batches are instead emplaced (a) at the level of the Moho, or at other density and/or rheology traps in the crust such as the brittle-ductile boundary between upper and lower crust (UC/LC), where they differentiate over centuries to millennia (b). When the stress regime becomes suitable (c), a second generation of basanite melt rises to the surface, collecting melt from the evolved crustal accumulations on its way to eruption. However, volcanism at the Waipiata volcanic field was long lived, with volcanoes of many different ages, suggesting that this is not an appropriate scenario. (d)-(f) show magma repeatedly injected to Moho or upper-lower-crustal levels. At these crustal or base of crust storage sites magma evolves to tephrite or phonotephrite. When a later basanite injection propagates into one of these magma bodies, the storage site is fractured and the more buoyant tephrite advances ahead of the ascending basanite to begin an eruption at the surface. (See text for further discussion.)

injected again from the same or newly formed adjacent source areas. When evolved magma bodies were encountered by later injections, the additional buoyancy provided by the entrained tephritic melts would have favoured propagation of these dykes to the surface. The degassing and expulsion of volatile phases upon mixing of two different magmas (the stalled and the newly intruded) would also have facilitated the propagation of dykes (Rubin 1995), as would the increased hydrostatic pressure developed in the crustal reservoir when encountered by newly intruding basanite dyke(s). In this scenario, basanite magma would rarely reach the surface unless an evolved, tephritic reservoir was encountered at mid-crustal depths, although exceptionally large batches of basanite might extend to the surface without a boost from tephrite buoyancy and/or increased hydrostatic pressure as a result of melt mixing. Diachronous eruptions, as indicated by existing dates, are more easily accommodated in this scenario. It also bears a strong physical resemblance to the model for the 1949 La Palma eruption, with the main distinction being that storage is not localized within the rift zones of a large volcanic system.

\section{Conclusion}

Continental monogenetic volcanic fields are subject to the same physical constraints as other volcanic systems. Dense mantlederived magmas are prone to ponding near their levels of neutral buoyancy, at depths of $25-30 \mathrm{~km}$, at the upper-mantle-continental crust boundary and/or in rheological and density contrast zones between the brittle-ductile transition at mid-crustal levels (Ryan 1987; Walker 1989; Lister 1991; Lister \& Kerr 1991;
Watanabe et al. 1999). Eruption of such magmas in small volumes requires substantial injected volumes of which only a small proportion reaches the surface, and/or specific stress conditions within the transected lithosphere (Watanabe et al. 1999). We have identified mechanisms that may help bring small volumes of magma to the surface, and suggest that where these mechanisms operate there should be a systematic presence of early erupted evolved rocks. These are commonly present as pyroclastic deposits rather than lava because their early arrival favours interaction with groundwater to produce phreatomagmatic eruptions, and/or because they have higher volatile contents. We are unable to assess the universality of this behaviour, because pyroclastic deposits have not been sampling targets for most petrological investigations. We find, however, similar compositional bimodality among early pyroclastic and subsequent effusive products associated with two widely spaced and unrelated volcanic fields, each of which is a typical intracontinental, monogenetic field, and each of which was at the time of volcanism exposed to only weak stresses related to nearby transcurrent plate boundaries. We conclude that similar compositional bimodality among eruptive products of intracontinental volcanoes in volcanic fields may be the rule, rather than the exception.

The authors thank A. Klügel (Universität Bremen, Germany) for helpful comments that strengthened the manuscript. Journal reviewers J. L. Smellie and D. A. Jerram, and Journal editor S. A. Gibson are thanked for their constructive suggestions. Funding for the research was provided by the University of Otago Postgraduate Scholarship to K.N. 


\section{References}

Balogh, K., Árva-Sós, E., Pécskay, Z. \& Ravasz-Baranyai, L. 1986. K/Ar dating of post-Sarmatian alkali basaltic rocks in Hungary. Acta Mineralogica et Petrographica, Szeged, 28, 75-94.

BARberi, F. \& VARET, J. 1970. The Erta Ale volcanic range (Danakil Depression, Northern Afar, Ethiopia). Bulletin of Volcanology, 34, 848-917.

Belousov, A. \& Belousova, M. 2001. Eruptive process, effects and deposits of the 1996 and the ancient basaltic phreatomagmatic eruptions in Karymskoye lake, Kamchatka, Russia. In: White, J.D.L. \& RigGs, N.R. (eds) Volcaniclastic Sedimentation in Lacustrine Settings. Special Publications of the International Association of Sedimentologists, 30, 35-60.

Bourdon, B., Zindler, A. \& Worner, G. 1994. Evolution of the Laacher See magma chamber-evidence from SIMS and TIMS measurements of U-Th disequilibria in minerals and glasses. Earth and Planetary Science Letters, 126, 75-90.

Brandon, A.D. \& Goles, G.G. 1995. Assessing subcontinental lithospheric mantle sources for basalts-Neogene volcanism in the Pacific-Northwest, USA as a test-case. Contributions to Mineralogy and Petrology, 121, 364-379.

Condomines, M., Tanguy, J.C. \& Michaud, V. 1995. Magma dynamics at Mt Etna-constraints from $\mathrm{U}-\mathrm{Th}-\mathrm{Ra}-\mathrm{Pb}$ radioactive disequilibria and $\mathrm{Sr}$ isotopes in historical lavas. Earth and Planetary Science Letters, 132, 25-41.

Connor, C.B. \& Conway, F.M. 2000. Basaltic volcanic fields. In: Sigurdsson, H., Houghton, B., McNutt, S., Rymer, H. \& Stix, J. (eds) Encyclopedia of Volcanoes. Academic Press, San Diego, CA, 331-343.

Connor, C.B., Stamatakos, J.A. \& Ferrill, D.A. et AL. 2000. Geologic factors controlling patterns of small-volume basaltic volcanism: application to a volcanic hazards assessment at Yucca Mountain, Nevada. Journal of Geophysical Research, Solid Earth, 105, 417-432.

Conway, F.M., Connor, C.B., Hill, B.E., Condit, C.D., Mullaney, K. \& HALL, C.M. 1998. Recurrence rates of basaltic volcanism in SP Cluster, San Francisco volcanic field, Arizona. Geology, 26, 655-658.

Coombs, D.S. \& ReAY, A. 1986. Cenozoic alkaline and tholeiitic volcanism, eastern South Island, New Zealand. Days 1 to 4. Dunedin Volcanic Group, Waiareka-Deborah Volcanics, Timaru Basalt. Excursion C2. Fieldtrip Guide-International Volcanological Congress, University of Otago, Dunedin.

Coombs, D.S., Cas, R.A., Kawachi, Y., Landis, C.A., McDonough, W.F. \& ReAY, A. 1986. Cenozoic volcanism in north, east and central Otago. In: Smith, I. (ed.) Cenozoic Volcanism in New Zealand. Royal Society of New Zealand Bulletin, 23, 278-312.

Donnelly, K.E. 1996. The Waipiata Volcanic Formation. MSc thesis, University of Otago.

DoubiK, P. \& Hill, B.E. 1999. Magmatic and hydromagmatic conduit development during the 1975 Tolbachik eruption, Kamchatka, with implications for hazards assessment at Yucca Mountain. Journal of Volcanology and Geothermal Research, 91, 43-64.

DudA, A. \& SchmincKe, H.U. 1978. Quaternary basanites, melilite nephelinites and tephrites from the Laacher See area (Germany). Neues Jahrbuch für Mineralogie, Abhandlungen, 132, 1-33.

Ebinger, C.J., Yemane, T., Woldegabriel, G., Aronson, J.L. \& Walter, R.C. 1993. Late Eocene-Recent volcanism and faulting in the Southern Main Ethiopian Rift. Journal of the Geological Society, London, 150, 99-108.

EMBEY-IsZTiN, A. 1993. A compilation of new major, trace element and isotope geochemical analyses of the young alkali basalts from the Pannonian Basin. Fragmenta Geologica et Petrographica, Budapest, 16, 5-26.

Fisher, R.V. \& SchmincKe, H.-U. 1984. Pyroclastic Rocks. Springer, Heidelberg.

FoDOR, L. 1995. From transpression to transtension; Oligocene-Miocene structural evolution of the Vienna Basin and the East Alpine-Western Carpathian junction. Tectonophysics, 242, 151-182.

HasenaKa, T. \& CARMichael, I.S.E. 1985. The cinder cones of MichoacánGuanajuato, central Mexico: their age, volume and distribution, and magma discharge rate. Journal of Volcanology and Geothermal Research, 25, $105-124$.

Hasenaka, T. \& Carmichael, I.S.E. 1987. The cinder cones of MichoacanGuanajuato, central Mexico: petrology and chemistry. Journal of Petrology, 28, 241-269.

Hawkesworth, C.J., Blake, S., Evans, P., Hughes, R., MacDonald, R., Thomas, L.E. \& Turner, S.P. 2000. Time scales of crystal fractionation in magma chambers-integrating physical, isotopic and geochemical perspectives. Journal of Petrology, 41, 991-1006.

HeAD, J.W. \& Wilson, L. 1992. Magma reservoirs and neutral buoyancy zones on Venus-implications for the formation and evolution of volcanic landforms. Journal of Geophysical Research - Planets, 97, 3877-3903.

Heiken, G.H. 1974. An Atlas of Volcanic Ash. Smithsonian Earth Science Contributions, 12.

Houghton, B.F. \& Schmincke, H.U. 1986. Mixed deposits of simultaneous strombolian and phreatomagmatic volcanism; Rothenberg Volcano, East Eifel volcanic field. Journal of Volcanology and Geothermal Research, 30, $117-130$.

Houghton, B.F. \& SchmincKe, H.-U. 1989. Rothenberg scoria cone, East Eifel; a complex strombolian and phreatomagmatic volcano. Bulletin of Volcanology, $\mathbf{5 2}, 28-48$.

Kienle, J., Kyle, P.R., Self, S., Motyka, R.J. \& Lorenz, V. 1980. Ukinrek Maars, Alaska, 1. April 1977 eruption sequence, petrology, and tectonic settings. Journal of Geophysical Research, 7, 11-37.

KING, P.R. 2000. Tectonic reconstructions of New Zealand: $40 \mathrm{Ma}$ to the Present New Zealand Journal of Geology and Geophysics, 43, 611-638.

KLÜGEL, A. 1997. Ascent rates of magmas and genesis, transport, and reactions of mantle and crystal xenoliths of the 1949 eruption on La Palma (Canary Island). $\mathrm{PhD}$ thesis, Christian Albrecht Universität, Kiel.

KLÜGEL, A. 1998. Reactions between mantle xenoliths and host magma beneath La Palma (Canary Islands): constraints on magma ascent rates and crustal reservoirs. Contributions to Mineralogy and Petrology, 131, 237-257.

KLÜGEL, A., Schmincke, H.U., White, J.D.L. \& Hoernle, K.A. 1999. Chronology and volcanology of the 1949 multi-vent rift-zone eruption on La Palma (Canary Islands). Journal of Volcanology and Geothermal Research, 94, 267-282.

Klügel, A., Hoernle, K., Schmincke, H.-U. \& White, J.D.L. 2000. The chemically zoned 1949 eruption on La Palma (Canary Islands): petrologic evolution and magma supply dynamics of a rift zone eruption. Journal of Geophysical Research, 105, 5997-6016.

Koons, P.O., Upton, P., Henderson, C.M., Enlow, R.L. \& Pearson, C.J. 1999. Otago versus Canterbury: basic differences in inherited geology and applied forces. In: Geological Society of New Zealand Miscellaneous Publications, $107 A, 82$.

Lister, J.R. 1991. Steady solutions for feeder dykes in a density-stratified lithosphere. Earth and Planetary Science Letters, 107, 233-242.

Lister, J.R. \& KERR, B.C. 1991. Fluid-mechanical models of crack propagation and their application to magma transport. Journal of Geophysical Research, 96, 10049-10077.

Martin, U. \& Németh, K. 2000. Peperite structures from the Bakony-Balaton Highland Volcanic Field (Pannonian Basin, Hungary): examples from the Hajagos-hegy. In: Terra Nostra (Alfred Wegener Stiftung, Potsdam, GermanyConference Proceeding for the 1st International Maar Conference, Daun, Germany), 2000/6, 318-329.

Moore, J.G., Nakamura, K. \& Alcaraz, A. 1966. The 1966 eruption of Taal volcano. Science, 155, 955-960.

Moore, R.B. 1992. Volcanic geology and eruption frequency, lower East Rift-Zone of Kilauea Volcano, Hawaii. Bulletin of Volcanology, 54, 475-483.

MülleR, G. \& VeYL, G. 1956. The birth of Nilahue, a new maar type volcano at Rininahue, Chile. In: Chile Congreso Geologico Internacional, Seccio IVulcanologia del Cenozoico. Mexico City, 375-396.

NÉMETH, K. 2000. Collapse structures of an eroded maar/diatreme volcanic field from Central Otago, New Zealand: the crater as an example. In: Terra Nostra (Alfred Wegener Stiftung, Potsdam, Germany-Conference Proceeding for the Ist International Maar Conference, Daun, Germany), 2000/6, 364-375.

NÉmeth, K. 2001. Phreatomagmatic volcanism at the Waipiata volcanic field, Otago, New Zealand. PhD thesis, University of Otago.

Németh, K. \& Martin, U. 1999. Large hydrovolcanic field in the Pannonian Basin: general characteristics of the Bakony-Balaton Highland Volcanic Field, Hungary. Acta Vulcanologica, 11, 271-282.

Németh, K., Korbély, B. \& Karátson, D. 2000. The Szigliget maar/diatreme, Bakony-Balaton Highland Volcanic Field (Hungary). In: Terra Nostra (Alfred Wegener Stiftung, Potsdam, Germany-Conference Proceeding for the 1st International Maar Conference, Daun, Germany), 2000/6, 375-383.

Reagan, M.K., Volpe, A.M. \& Cashman, K.V. 1992. U-238 series and Th-232 series chronology of phonolite fractionation at Mount Erebus, Antarctica. Geochimica et Cosmochimica Acta, 56, 1401-1407.

Rubin, A.M. 1995. Propagation of magma-filled cracks. Annual Review of Earth and Planetary Sciences, 23, 287-336.

RYAN, M.P. 1987. Neutral buoyancy and the mechanical evolution of magmatic systems. In: Mysen, B.O. (ed.) Magmatic Processes: Physico-chemical Principles. Geochemical Society, University Park, PA, 259-287.

SCHMincKe, H.-U. 1977a. Eifel-Vulkanismus ostlich des Gebietes Rieden-Mayen. Fortschritte der Mineralogie, 55, 1-31.

SCHMincKe, H.-U. 1977b. Phreatomagmatische Phasen in quartaeren Vulkanen der Osteifel. Geologische Jahrbuch, A39, 3-45.

Schmincke, H.-U., LoRenZ, V. \& SEck, H.A. 1983. The Quaternary Eifel volcanic fields. In: Fuchs, K. (ed.) Plateau Uplift. Springer, Berlin, 139-151.

Self, S., Kienle, J. \& Huot, J.-P. 1980. Ukinrek Maars, Alaska, II. Deposits and formation of the 1977 Crater. Journal of Geophysical Research, 7, 39-65.

Sparks, R.S.J., Pinkerton, H. \& Macdonald, R. 1977. The transport of xenoliths in magma. Earth and Planetary Science Letters, 35, 234-238.

SPERA, F.J. 1984. Carbon dioxide in petrogenesis III: role of volatiles in the ascent of alkaline magma with special reference to xenolith-bearing mafic lavas. Contributions to Mineralogy and Petrology, 88, 217-232. 
Szabó, C. \& BodnaR, R.J. 1996. Changing magma ascent rates in the NógrádGömör volcanic field, Northern Hungary/Southern Slovakia: evidence from $\mathrm{CO}_{2}$-rich fluid inclusions in metasomatized upper mantle xenoliths. Petrology, 4, 221-230.

Thorarinsson, S. 1967. Surtsey. The New Island in the North Atlantic. Viking Press, New York.

Turner, S., Bourdon, B., Hawkesworth, C.J. \& Evans, P. 2000. Ra-226-Th230 evidence for multiple dehydration events, rapid melt ascent and the time scales of differentiation beneath the Tonga-Kermadec island arc. Earth and Planetary Science Letters, 179, 581-593.

WALKER, G.P.L. 1989. Gravitational (density) controls on volcanism, magma chambers and intrusions. Australian Journal of Earth Sciences, 36, 149-165.

Walker, G.P.L. 1993. Basaltic-volcano systems. In: Prichard, H.M., Alabaster, T., Harris, N.B.W. \& Neary, C.R. (eds) Magmatic Processes and Plate Tectonics. Geological Society, London, Special Publications, 68, 3-38.
Watanabe, T., Koyaguchi, T. \& Seno, T. 1999. Tectonic stress controls on ascent and emplacement of magmas. Journal of Volcanology and Geothermal Research, 91, 65-78.

White, J.D.L. 1991. Maar-diatreme phreatomagmatism at Hopi Buttes, Navajo Nation (Arizona), USA. Bulletin of Volcanology, 53, 239-258.

White, J.D.L. \& Houghton, B.F. 2000. Surtseyan and related eruptions. In: Sigurdsson, H., Houghton, B., McNutt, S., Rymer, H. \& Stix, J. (eds) Encyclopedia of Volcanoes. Academic Press, San Diego, CA, $495-512$.

White, J.D.L. \& Schmincke, H.U. 1999. Phreatomagmatic eruptive and depositional processes during the 1949 eruption on La Palma (Canary Islands). Journal of Volcanology and Geothermal Research, 94, 283-304.

Widom, E., Schmincke, H.U. \& Gill, J.B. 1992. Processes and timescales in the evolution of a chemically zoned trachyte-Fogo-a, São-Miguel, Azores. Contributions to Mineralogy and Petrology, 111, 311-328.

Received 1 October 2002; revised typescript accepted 3 March 2003.

Scientific editing by Sally Gibson 


\section{Compositional variation during} monogenetic volcano growth and its implications for magma supply to continental volcanic fields

Nemeth, Karoly

2003-01-01

http://hdl.handle.net/10179/9610

22/04/2023 - Downloaded from MASSEY RESEARCH ONLINE 